\title{
Tenacibaculum sp. associated with winter ulcers in sea-reared Atlantic salmon Salmo salar
}

\author{
A. B. Olsen ${ }^{1, *}$, H. Nilsen ${ }^{1}$, N. Sandlund ${ }^{2}$, H. Mikkelsen ${ }^{3}$, H. Sørum ${ }^{4}$, D. J. Colquhoun ${ }^{5}$ \\ ${ }^{1}$ National Veterinary Institute Bergen, 5811 Bergen, Norway \\ ${ }^{2}$ Institute of Marine Research, 5817 Bergen, Norway \\ ${ }^{3}$ Nofima Marin, 9291 Tromsø, Norway \\ ${ }^{4}$ Norwegian College of Veterinary Medicine, 0033 Oslo, Norway \\ ${ }^{5}$ National Veterinary Institute Oslo, 0106 Oslo, Norway
}

\begin{abstract}
Coldwater-associated ulcers, i.e. winter ulcers, in seawater-reared Atlantic salmon Salmo salar L. have been reported in Norway since the late 1980s, and Moritella viscosa has been established as an important factor in the pathogenesis of this condition. As routine histopathological examination of winter ulcer cases in our laboratory revealed frequent presence in ulcers of long, slender rods clearly different from $M$. viscosa, a closer study focusing on these bacteria was conducted. Field cases of winter ulcers during 2 sampling periods, 1996 and 2004-2005, were investigated and long, slender rods were observed by histopathological examination in 70 and $62.5 \%$ of the ulcers examined, respectively, whereas cultivation on marine agar resulted in the isolation of yellowpigmented colonies with long rods from 3 and $13 \%$ of the ulcers only. The isolates could be separated into 2 groups, both identified as belonging to the genus Tenacibaculum based on phenotypic characterization and 16S rRNA sequencing. Bath challenge for $7 \mathrm{~h}$ confirmed the ability of Group 1 bacterium to produce skin and cornea ulcers. In fish already suffering from $M$. viscosa-induced ulcers, co-infection with the Group 1 bacterium was established within $1 \mathrm{~h}$. Ulcers from field cases of winter ulcers and from the transmission experiments tested positive by immunohistochemistry with polyclonal antiserum against the Group 1 bacterium but not the Group 2 bacterium. Our results strongly indicate the importance of the Group 1 bacterium in the pathogenesis of winter ulcers in Norway. The bacterium is difficult to isolate and is therefore likely to be underdiagnosed based on cultivation only.
\end{abstract}

KEY WORDS: Winter ulcers · Tenacibaculum • Atlantic salmon · Transmission experiment . Moritella viscosa $\cdot$ Cod $\cdot$ Halibut

Resale or republication not permitted without written consent of the publisher

\section{INTRODUCTION}

The occurrence of winter ulcers, i.e. coldwater-associated skin lesions in Atlantic salmon Salmo salar L., usually seen at sea temperatures below $8^{\circ} \mathrm{C}$, is currently a significant bacterial disease problem in salmon farming in Norway. Although cumulative mortalities are usually below $10 \%$, a large proportion of the fish on a site may be affected and there are often considerable economical losses due to downgrading at slaughter. As fish may exhibit extensive ulceration over extended periods, winter ulcers are also creating an important fish welfare concern. While aetiology and pathogenesis are not fully elucidated, the bacterium Moritella viscosa (prev. Vibrio viscosus) is considered to be an important factor in the pathogenesis of winter ulcers in Norway, Iceland and Scotland (Lunder et al. 1995, Benediktsdóttir et al. 1998, Bruno et al. 1998). $M$. viscosa has been shown to cause skin ulcers, septicaemia and mortality in transmission experiments (Lunder et al. 1995, Løvoll et al. 2009). Despite the availability and widespread use of vaccines against $M$. viscosa, winter ulcers remains a significant threat. Vibrio wodanis is also frequently isolated from fish with 
winter ulcers (Lunder et al. 1995, Benediktsdóttir et al. 1998); however, demonstration of pathogenicity for this bacterium under experimental conditions has so far been unsuccessful (Lunder et al. 1995). Many culture-based investigations of winter ulcers have resulted in the identification of mixed cultures of mainly Vibrio spp. (Benediktsdóttir et al. 1998, H. Nilsen \& A. B. Olsen unpubl.).

Worldwide, members of the Cytophaga-Flavobacterium-Bacterioides group are reported to cause mortality and economical losses because of skin ulcers and eroded fins of both freshwater and seawater fish species (Wakabayashi et al. 1986, Kent et al. 1988, Bernardet 1989, Bernardet \& Kerouault 1989, Bernardet et al. 1990). The bacteria appear as yellow colonies with long, slender filamentous rods and are relatively difficult to culture. Four species are considered pathogenic to salmonids: Flavobacterium branchiophilum (bacterial gill disease in freshwater), $F$. columnare (freshwater above $14^{\circ} \mathrm{C}$ ), F. psychrophilum (mainly rainbow trout in freshwater) and Tenacibaculum maritimum (prev. Flexibacter maritimus) in seawater (Borg 1960, Wakabayashi et al. 1986, 1989, Kent et al. 1988, Bernardet 1989, Bernardet \& Grimont 1989, Bernardet \& Kerouault 1989, Bernardet et al. 1990). T. maritimum has never been isolated in Norwegian ulcer cases.

Over the years, at the National Veterinary Institute Bergen (NVIB), routine histopathological examination of skin ulcers in sea-farmed Atlantic salmon during the winter season has revealed the presence of long, slender bacteria appearing either alone or as a mixed infection with Moritella viscosa and/or other bacteria. The aim of the present study was to identify - through microbiological, histopathological, immunohistochemical and transmission studies - the importance of these bacteria for the development of winter ulcers in Atlantic salmon.

\section{MATERIALS AND METHODS}

Sampling. Samples for pathological, histopathological and microbiological investigation of skin ulcers in sea-reared Atlantic salmon were collected from January to April 1996 and between December 2004 and April 2005 (Table 1). During the 1996 sampling, field veterinarians were asked to submit fish and formalinfixed tissues for standardized laboratory examination. Samples representing 18 outbreaks of winter ulcers were submitted by 13 fish health practitioners. During 2004-2005, 2 outbreaks of winter ulcers were each sampled 3 times between December and April. Sampling was performed in these cases by staff of the NVIB.

For comparative purposes, 8 historical cases were included (Table 2), comprising samples for histopatho-

Table 1. Salmo salar. Results from histopathological and immunohistopathological investigation of winter ulcers in Atlantic salmon with focus on the detection of long, slender rods during 2 sampling periods. IHC: immunohistochemistry; n: total number investigated

\begin{tabular}{|c|c|c|c|c|c|c|}
\hline \multirow[t]{2}{*}{ Year } & \multirow[t]{2}{*}{ Month } & \multirow{2}{*}{$\begin{array}{c}\text { Fish weight } \\
(\mathrm{kg})\end{array}$} & \multirow{2}{*}{$\begin{array}{l}\text { Winter ulcer } \\
\text { outbreaks (n) }\end{array}$} & \multirow{2}{*}{$\begin{array}{l}\text { Skin ulcers with long, } \\
\text { slender rods detected by } \\
\text { histopathology }(\%)\end{array}$} & \multicolumn{2}{|c|}{ IHC-positive (\%) } \\
\hline & & & & & $\begin{array}{l}\text { Group } 1 \\
\text { antiserum }\end{array}$ & $\begin{array}{c}\text { Group } 2 \\
\text { antiserum }\end{array}$ \\
\hline 1996 & Jan-Apr & $0.5-3.0$ & 18 & $70^{\mathrm{a}}(\mathrm{n}=56)$ & $100(n=18)$ & $0(\mathrm{n}=18)$ \\
\hline 2004-2005 & Dec-Apr & $0.5-3.7$ & $2^{\mathrm{b}}$ & $62.5(\mathrm{n}=32)$ & $100(\mathrm{n}=13)$ & $0(\mathrm{n}=13)$ \\
\hline
\end{tabular}

Table 2. Salmo salar, Hippoglossus hippoglossus, Gadus morhua and Oncorhynchus mykiss. Results of immunohistochemical investigation of historical samples with long, slender rods detected by histopathology. IHC: immunohistochemistry; +: positive result; -: negative result; nt: not tested

\begin{tabular}{|c|c|c|c|c|c|c|c|}
\hline Year & Case & Species & Organ & $\begin{array}{c}\text { Samples } \\
\text { investigated }\end{array}$ & $\begin{array}{l}\text { IHC Group } 1 \\
\text { antiserum }\end{array}$ & $\begin{array}{l}\text { IHC Group } 2 \\
\text { antiserum }\end{array}$ & $\begin{array}{c}\text { IHC Moritella } \\
\text { viscosa antiserum }\end{array}$ \\
\hline 1988 & F1409/88 & Atlantic salmon & Skin ulcer & 1 & + & $\mathrm{nt}$ & nt \\
\hline 2000 & $\mathrm{~F} 41 / 00$ & Atlantic salmon & Gill $^{\mathrm{a}}$ & 1 & + & - & - \\
\hline 2001 & F187/01 & Atlantic salmon & Dorsal fin & 1 & + & - & - \\
\hline 2002 & F48/02 & Atlantic salmon & Eye (cornea) & 1 & + & - & - \\
\hline 2002 & F101/02 & Halibut & Skin ulcer & 2 & + & - & - \\
\hline 2005 & F119/05 & Atlantic cod & Skin ulcer & 1 & + & - & - \\
\hline 2005 & F90/05 & Rainbow trout & Skin ulcer & 1 & + & - & - \\
\hline
\end{tabular}


logical examination of gill, eye and dorsal fin of Atlantic salmon and skin ulcers from Atlantic salmon diagnosed with winter ulcers in 1988, rainbow trout Oncorhynchus mykiss brood fish, Atlantic cod Gadus morhua and halibut Hippoglossus hippoglossus. Additional bacterial isolates were collected from historical winter ulcer cases submitted to the laboratory at NVIB by field veterinarians.

Bacteriology. For bacteriological examination, samples from kidney and the border of skin ulcers were inoculated onto blood agar ( $4 \%$ bovine/ovine blood) (BA), blood agar supplemented with $1.5 \% \mathrm{NaCl}$ (BAS) and marine agar (Difco Marine Agar 2216) (MA). The plates were incubated for $7 \mathrm{~d}, \mathrm{BA}$ at $22^{\circ} \mathrm{C}$ and MA and BAS at $15^{\circ} \mathrm{C}$.

Yellow colonies on MA were examined by phasecontrast microscopy. Colonies consisting of long, slender rods were further characterized for the presence of pigment, colony and cell morphology and Gram-stain affinity. The bacteria were tested for growth on BA, BAS and Anacker and Ordal's medium (Anacker \& Ordal 1959). Growth temperatures were tested by incubation on $\mathrm{MA}$ at $4,15,22$ and $30^{\circ} \mathrm{C}$. Anaerobic growth was tested on MA incubated for $5 \mathrm{~d}$ at $22^{\circ} \mathrm{C}$ using the GENbox test system (bioMérieux). Catalase production was tested using $10 \% \mathrm{H}_{2} \mathrm{O}_{2}$, and the presence of cytochrome oxidase was demonstrated using the filter paper strip test (Merck). The presence of flexirubin-type pigments was demonstrated by covering the colonies with $10 \% \mathrm{KOH}$ solution (Fautz \& Reichenbach 1980). Isolates were examined for an extracellular galactosamine glycan by flooding colonies with a $1 \%$ Congo-red solution (Johnson \& Chilton 1966). API ZYM strips (bioMérieux), incubated at $22^{\circ} \mathrm{C}$ for 18 to $20 \mathrm{~h}$, were used to test 19 enzymatic activities. Identification of Moritella viscosa was performed according to standard National Veterinary Institute (NVI) procedures.

16S rRNA gene sequencing. Nearly complete $16 \mathrm{~S}$ rRNA genes were amplified using PCR and primers described by Weisburg et al. (1991). The amplicon was then sequenced using the same primers and the internal sequencing primers $\mathrm{V} 1$ (5'-ACT GCT GCC TCC CGT-3'), V2 (5'-CTA CCA GGG TAT CTA ATC-3'), V3 (5'-GTA GTC CAC GCC GTA AAC G-3'), V4 (5'-GTT TAT CAC CGG CAG TCT C-3'), V5 (5'-GTC CAC ACT CCT ACG GGA GGC-3') and V6 (5'-GGG GAY GAC GTC AAG TC-3'). A DYEnamic ${ }^{\text {TM }}$ ET dye terminator cycle sequencing kit and a MEGABACE 1000 capillary sequencer (Amersham Biosciences) were used. Contiguous sequences were assembled, aligned and compared using Sequencher 4.5 (Gene Codes).

Phylogenetic analysis. The obtained sequences were compared with existing sequences in GenBank using BLAST search analysis (Altschul et al. 1990). The obtained sequences and sequences accessed from GenBank were then aligned in Clustal X (Thompson et al. 1997) and neighbour-joining (Kimura 2-parameter) analysis was performed in PAUP* 4.0 (Swofford 2000). Missing and ambiguous bases were excluded. Bootstrap confidence values were obtained with 1000 resamplings.

Antisera. Antisera were raised in gray chinchilla rabbit against representatives of subsequently described Groups 1 (isolate F140/96) and 2 (isolate F95C/98). The isolates were grown in marine broth (Difco Marine Broth 2216) (MB) and incubated at $15^{\circ} \mathrm{C}$ for $2 \mathrm{~d}$. The harvested cells were washed 3 times in phosphate-buffered saline (PBS), pH 7.3, resuspended in PBS and formaldehyde $(40 \%)$ was added for a final concentration of $0.5 \%$. For the F140/96 isolate, the suspension was incubated at $15^{\circ} \mathrm{C}$ for $1 \mathrm{~h}$, washed 3 times and then standardized to McFarland standard 3. A volume of $1 \mathrm{ml}$ of the formalinkilled cells emulsified with Freunds Complete adjuvant was injected intravenously on Days 1, 4, and 7 and a volume of $2 \mathrm{ml}$ was injected on Days 12, 15 and 20. Serum was collected on Day 28. For the F95C/98 isolate, the procedure described by Sørensen \& Larsen (1986) was followed.

Specificity of antisera. Specificity of the antisera was tested using the slide-agglutination test. The bacteria were mixed with undiluted antiserum on a microscopic slide using a careful rocking motion. A distinct agglutination within 1 min was recorded as positive. Additional bacteria tested with this method were Tenacibaculum maritimum (NCIMB 2154), T, ovolyticum (NCIMB 13127), T. gallaicum (CECT7123), T. soleae (CECT7292), T. discolor (NCIMB14278), T. lutimaris (DSM 16505), T. skagerrakense (DSM 14836), T. mesophilum (IFO 16307), T. amylolyticum (IFO 16310), Flavobacterium psychrophilum 386/94, Moritella viscosa (88/478), Vibrio wodanis (88/441) and V. anguillarum (ATCC 14181).

Histopathology. Samples from skin lesions were fixed in $10 \%$ buffered formalin and embedded in paraffin, according to standard procedures. Sections ( 3 to $5 \mu \mathrm{m}$ ) were stained with haematoxylin and eosin (H\&E) and using the May-Grünwald-Giemsa (MGG) method.

Immunohistochemistry. Sections of skin lesions revealing long, slender rods were treated with the antisera described, using avidin-biotin alkaline phosphatase procedures. All samples from 1996, the first sampling period, were tested with an avidin-biotin enzyme complex $(\mathrm{ABC})$ method using new fuchsin as the chromogen. All samples collected later and a selection of the 1996 samples were tested with the enzymelabeled streptavidin procedure (LAB) with fast red as the chromogen. Specifically, after deparaffinization (and, for the 1996 samples, pre-treatment with metha- 
nolic $\mathrm{H}_{2} \mathrm{O}_{2}$ ), the sections were overlaid with $5 \%$ bovine serum albumin (BSA) for $20 \mathrm{~min}$. The sections were then blotted without washing and incubated with the antiserum, diluted 1:1000, for $30 \mathrm{~min}$ at room temperature. The secondary antibody, biotinylated goat antirabbit (DakoCytomation E 0432) diluted 1:300, was added after washing in wash buffer. Following $30 \mathrm{~min}$ incubation and additional washing, $\mathrm{ABC}$-reagent or streptavidin alkaline phosphatase was added, respectively. Substrate-chromogen solution was applied and, after the development of desired colour, sections were gently rinsed and counterstained with haematoxylin.

Preparations of bacterial cultures for challenge. For challenge, the presumptive Tenacibaculum sp. Group 1 isolate F95B/98 and Group 2 isolate F95C/98 were chosen. The Moritella viscosa isolate (LF1 5006) was obtained from Atlantic salmon suffering from winter ulcers in sea cages at the Tromsø Aquaculture Research Station.

The bacteria were grown from MB/glycerol culture at $-80^{\circ} \mathrm{C}$, Moritella viscosa on BAS plates and F95B/98 and F95C/98 on MA. Several pure colonies were inoculated in $\mathrm{MB}$ and pre-cultured at $9^{\circ} \mathrm{C}$ (Expts 1 and 2) or $12^{\circ} \mathrm{C}$ (Expt 3) for $48 \mathrm{~h}$. Before use in bath challenge experiments, the bacteria were further sub-cultured for $24 \mathrm{~h}$ in larger volumes of MB until final absorbance at $600 \mathrm{~nm}$ reached 0.6 to 1 (U 1100 spectrophotometer, Hitachi). The cell concentration was determined by counting colony forming units (CFU) using a Hawksley counting chamber (Expts 1 and 2) or manually with a colony counter pen (Expt 3).

Fish. Three batches of smoltified Atlantic salmon of average weight 250 to $300 \mathrm{~g}$ were used. The smolts

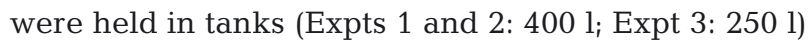
with UV-treated filtered seawater with a salinity of $34.5 \%$ taken from a depth of $120 \mathrm{~m}$. The fish were exposed to $12 \mathrm{~h}$ of artificial light and were fed continuously during the daylight period with commercial feed until they were used in 3 separate challenge experiments. The water temperature was $9.5^{\circ} \mathrm{C}$ throughout the challenge periods in Expts 1 and 2, and was $12^{\circ} \mathrm{C}$ in Expt 3. The different groups were tagged by injection of fluorescent dyes (elastomer tagging) above the eye in Expts 1 and 2, or by clipping of the left or right abdominal fin in Expt 3. Prior to tagging and exposure, the fish were anaesthetized using benzocaine in seawater $\left(50 \mathrm{mg} \mathrm{l}^{-1}\right)$. During the period of exposure, the water level was reduced to $100 \mathrm{l}$, oxygenated and the bacterial cultures were added directly to the water.

Expt 1: Challenge with Tenacibaculum spp. Fish with and without the induction of mechanical skin damage were kept in the same tank and were bathchallenged simultaneously with the presumptive Tenacibaculum sp. isolates F95B/98 and F95C/98. Prior to bath challenge, 15 of 20 fish were deeply scar- ified by removing scales covering an area of $1 \times 0.5 \mathrm{~cm}$ by extensive scraping with a scalpel leaf, approximately $1 \mathrm{~cm}$ below dorsal fin. For 7 of the scarified fish, 2 to 3 drops of each bacterial culture were applied on the scarified area for $12 \mathrm{~s}$. The fish were then bathchallenged simultaneously for $1 \mathrm{~h}$ with both isolates, F95B/98 $\left(1.2 \times 10^{6} \mathrm{CFU} \mathrm{ml}^{-1}\right)$ and F95C/98 $\left(1.8 \times 10^{6}\right.$ $\mathrm{CFU} \mathrm{ml}{ }^{-1}$ ).

Expt 2: Challenge with Moritella viscosa and Tenacibaculum spp. The purpose of this experiment was to determine whether skin ulcers caused by $M$. viscosa infection had any impact on infection with presumptive Tenacibaculum sp. isolates F95B/98 and F95C/98. Atlantic salmon were distributed in 2 tanks of $400 \mathrm{l}, 20$ fish in each tank, and bath challenged for $1 \mathrm{~h}$ with 2 doses $\left(1.3 \times 10^{8}\right.$ and $\left.6.4 \times 10^{8} \mathrm{CFU} \mathrm{ml}^{-1}\right)$ of $M$. viscosa LF1 5006. At Day 5 post-challenge, mortality was low in both groups (1 and 5 dead fish in low and high dose, respectively) and the 2 groups were mixed. Fifteen and 11 fish from low and high dose groups, respectively, were transferred to one tank (Tank A) whereas 4 fish from each group were kept in Tank B (mono-infection with $M$. viscosa). At Day 6, the fish in Tank A were bath-challenged for $1 \mathrm{~h}$ simultaneously with both F95B/98 $\left(6.4 \times 10^{5} \mathrm{CFU} \mathrm{ml}^{-1}\right)$ and F95C/98 $\left(1.2 \times 10^{6} \mathrm{CFU} \mathrm{ml}^{-1}\right)$. Twenty non-treated fish were kept in a third tank (Tank C).

Expt 1 lasted for $28 \mathrm{~d}$ and Expt 2 lasted for $24 \mathrm{~d}$. Mortality was recorded daily and dead and moribound fish were removed and examined. In Expt 1, the first samples were taken after $4 \mathrm{~d}$ ( 2 fish) and in Expt 2 after $1 \mathrm{~d}$ (1 fish). Post-mortem examination was performed and samples were taken for histopathology (normal skin, skin lesions and internal organs) and bacteriology (normal skin, skin lesions and kidney). A selection of skin lesions were tested for bacteria using immunohistochemistry.

Expt 3: Challenge with Group 1 strain of Tenacibaculum sp. The purpose of this experiment was to determine whether infection with only the Group 1 F95B/98 isolate of presumptive Tenacibaculum sp. and prolonged exposure time produced skin lesions. Prior to bath challenge, 10, 6 and 8 fish were subjected to either deep, superficial or no scarification, respectively. The fish were equally distributed in 2 tanks and fish in Tank 1 were bath challenged for $7 \mathrm{~h}$ with the isolate F95B/98 $\left(4.2 \times 10^{7} \mathrm{CFU} \mathrm{ml}^{-1}\right)$ whereas fish in Tank 2 constituted non-infected controls. The fish were observed every day for $14 \mathrm{~d}$ and abnormal behaviour and external lesions were recorded. From Day 3, one fish in the exposed group was sampled every second day. Post-mortem examination was performed and samples were taken for histopathology (skin lesions and internal organs) and bacteriology (normal skin, skin lesions and kidney, 
MA, BA, BAS). At the end of the experiment, all surviving fish in the exposed group were killed and samples were collected. A selection of skin lesions were tested for F95B/98 using immunohistochemistry.

To investigate whether the MB itself affected the fish, remaining individuals from the control group of Expt 3 were divided into 2 groups. Four deeply skinscarified fish and one non-scarified fish were exposed to sterile MB (3 l/100 l water) for $5.5 \mathrm{~h}$. Three deeply skin-scarified fish and one non-scarified fish served as controls in a separate tank. The fish were kept and observed for $8 \mathrm{~d}$.

\section{RESULTS}

\section{Gross pathology}

Gross pathological examination of fish collected from field cases during the 2 study periods revealed a prevalence of one ulcer per fish of $71 \%$ (53/75 fish from 18 outbreaks) and $74 \%$ (28/38), respectively. Otherwise, the fish suffered from multiple ulcers. For a minority of fish (4\%), the ulcer included the dorsal fin. In some individuals (13\%), erosion of the mouth and head regions was seen.

\section{Isolation of long, slender bacteria}

In 1996, investigation of skin lesions by cultivation on MA from a total of 75 fish (18 outbreaks) resulted in isolation of long, slender bacteria from 2 ulcers (3\%), one from each of 2 outbreaks, whereas in 2004-2005 such bacteria were isolated from both outbreaks investigated and from 9 of the 25 (36\%) ulcers examined by cultivation. The bacteria were not isolated from the kidneys.

\section{Phenotypic characterization of the bacteria}

Isolates consisting of long, slender rods on MA could be separated into 2 groups according to colony colour. The first group (Group 1) was moderately yellow in colour whereas the second group (Group 2) displayed bright yellow colonies. In contrast to Group 1 isolates, Group 2 isolates did grow on BAS. No growth on Anacker and Ordal's medium was observed. The bacteria formed thread-like, flexible cells; Group 1 cells measured between 10 and $60 \mu \mathrm{m}$ whereas Group 2 cells were shorter, 6 to $20 \mu \mathrm{m}$. Both presented spherical, degenerative inflations and coccoid bodies with age. The Group 1 and 2 isolates were Gram-negative, strictly aerobic, cytochrome oxydase- and catalase- positive (weak reaction), degraded gelatin and did not have flexirubin-type pigments, but were Congo red positive. They grew well on MA and growth was seen at 4,15 and $22^{\circ} \mathrm{C}$, but not at $30^{\circ} \mathrm{C}$. When tested by API ZYM, they were positive for alkaline phosphatase, esterase, esterase lipase, lipase (very weak), leucine arylamidase, valine arylamidase, cystine arylamidase, phosphatase acid, naphtolphospo-hydrolase and negative to trypsine, chymotrypsine, $\alpha$-galactosidase, $\beta$ galactosidase, $\beta$-glucoronidase, $\alpha$-glucosidase, $\beta$-glucosidase, $n$-acetyl $\beta$-glucosaminidase, $\alpha$-mannosidase and $\alpha$-fucosidase.

\section{Molecular analysis}

The results from the $16 \mathrm{~S}$ rDNA analysis are summarized in Fig. 1. The 16S rDNA sequences from the NCBI databases most similar to the 2 presumptive Tenacibaculum spp. F95B/98 and F95C/98 in the present study all belong to the genus Tenacibaculum.

By NCBI BLAST, the 16S rDNA sequence from Tenacibaculum sp. F95B/98 had $97 \%$ identity with the 16S rDNA sequence from T. solea LL04 (AM746476.1) and $96 \%$ with T. ovolyticum IFO15947 (AB078058) and IFO 15993 (AB032508) as its closest relatives. Similarly, the 16S rDNA sequence of Tenacibaculum sp. F95C/98 had $96 \%$ identity with the same 3 sequences.

On phylogenetic comparison of the obtained $16 \mathrm{~S}$ rDNA sequences (Fig. 1), the 7 isolates studied clustered into 2 closely related yet separate clusters with Tenacibaculum ovolyticum as their closest known relative, with one cluster containing the 4 isolates belonging to phenotypical Group 1 exclusively, and the second containing Group 2 isolates. Intra-cluster sequence identities in both cases were $99 \%$ whereas the 2 novel clusters exhibited sequence identity values of $98 \%$ with each other.

The 16S rRNA gene sequences were submitted to GenBank under the following accession numbers: F95B/98, GU124769; F140/96, GU124770; F78-6R/98, GU124767; F112C/98, GU124761; F95C/98, GU124769; F16_98/F98_98, GU124761; and F78-6-ulcer/98, GU 123761.

\section{Histopathology}

Histopathological examination revealed the presence of long, slender rods in skin ulcers in all 18 outbreaks investigated in 1996 and at all sample points at both farms sampled during 2004-2005. The prevalence of the bacteria in the ulcers as observed by histopathology was 70 and $62.5 \%$ for the 2 sampling periods, respectively (Table 1 ). 


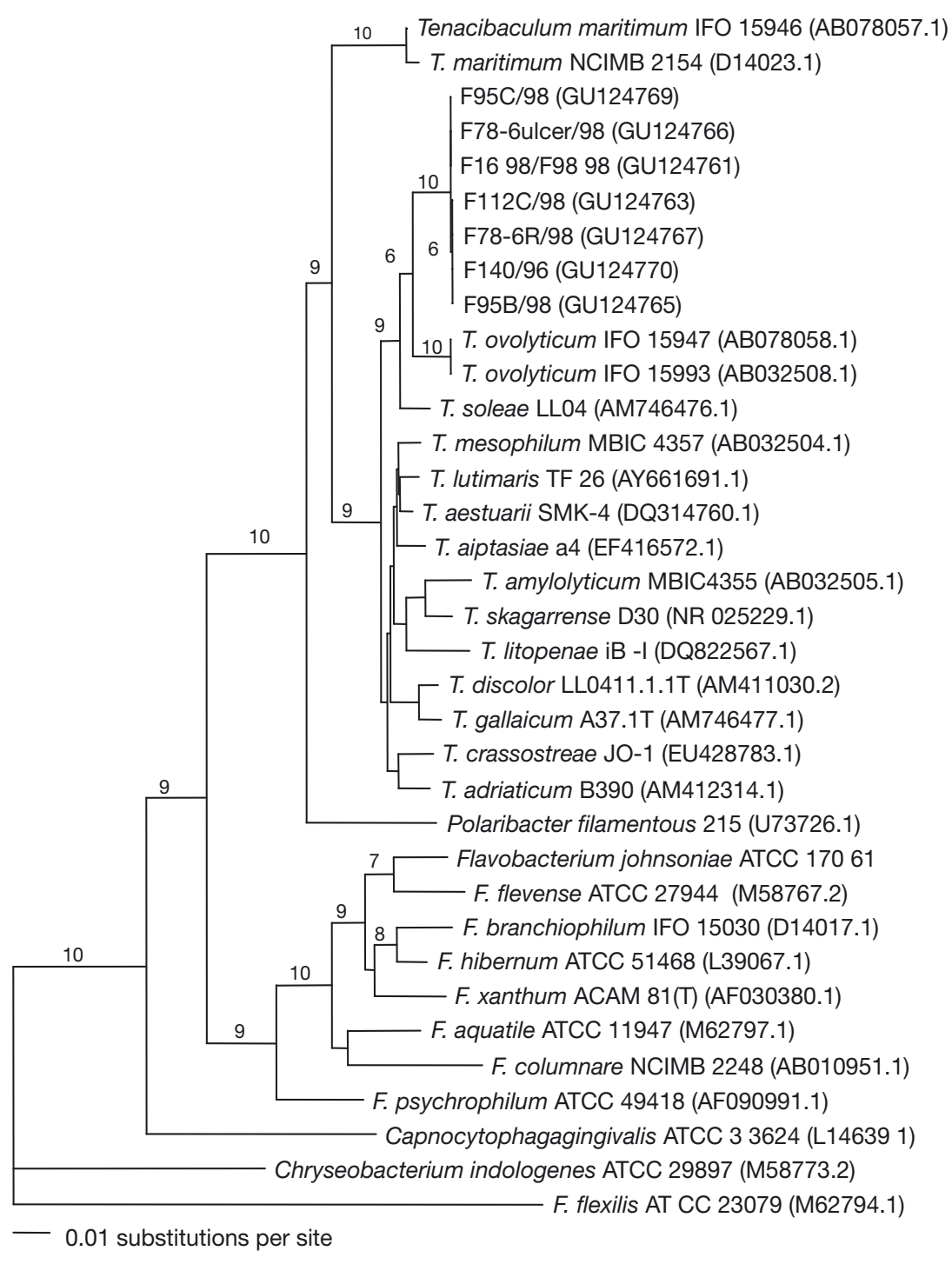

Fig. 1. Phylogenetic tree showing relationships between four Group 1 isolates (F95B/98, F140/96, F78-6R/98 and F112C/98), three Group 2 isolates (F95C/98, F78-6ulcer/98 and F16_98/F98_98) and related organisms based on nearly complete $16 \mathrm{~S}$ rDNA sequences. Scale bar represents the number of base substitutions per site. Accession numbers for sequences derived from reference strains are in parentheses

The bacteria were only observed in open lesions in which the epidermis was disrupted. The long, slender rods were most often located in the superficial and exposed parts of the lesions. The bacteria appeared to be aligned along the collagen fibres of the dermis and could be present in large numbers. Long, slender rods were also, on occasion, observed extending deeply into intermuscular connective tissue and muscle fibres. Histological examination of skin lesions also revealed small, curved bacteria (possibly Moritella viscosa) as a prominent but not consistent finding.
In the areas where the long rods were the dominating bacterium, no inflammatory responses, with the exception of occasional findings consistent with oedema, were seen. In one historical case including damaged eyes (Table 2), long, slender rods were seen to colonise the cornea and were the only bacteria observed.

\section{Specificity of antisera}

By slide-agglutination test, there was no cross-reaction between the Group 1and Group 2-type bacteria or with the panel of bacteria tested.

\section{Immunohistochemistry}

All tissue sections from field cases involving Atlantic salmon, halibut, Atlantic cod and rainbow trout showing long, slender rods stained positive with rabbit antisera against Group 1 (F140/96) but not with antisera against Group 2 (F95C/98), as shown by immunohistochemistry (Tables 1 \& 2). Occasionally a small proportion of long rods in an ulcer did not stain with either antisera.

\section{Challenge experiments}

In Expt 1, where fish were bath challenged with both F95B/98 and F95C/98, all 15 scarified fish developed an ulcer in the scarified area of 2 to $3 \mathrm{~cm}$ in diameter. There was no difference between fish that had their scarified area challenged by drops of bacterial culture before bath challenge and scarified fish that were only bath challenged. None of the fish died. An inflammatory response, but no bacteria, was detected histologically and no antigen was detected with immunohistochemistry against either bacteria. No skin lesions were observed in non-scarified fish.

In Expt 2, 8 of the 26 fish challenged with F95B/98 and F95C/98 $6 \mathrm{~d}$ following development of Moritella viscosa-induced ulcers died. Ulcers from 16 fish were examined.

Histopathological examination revealed the occurrence of long, slender rods in 11 of the 16 ulcers (69\%). All of these 11 ulcers were co-infected with small, curved rods, consistent with Moritella viscosa. In 3 

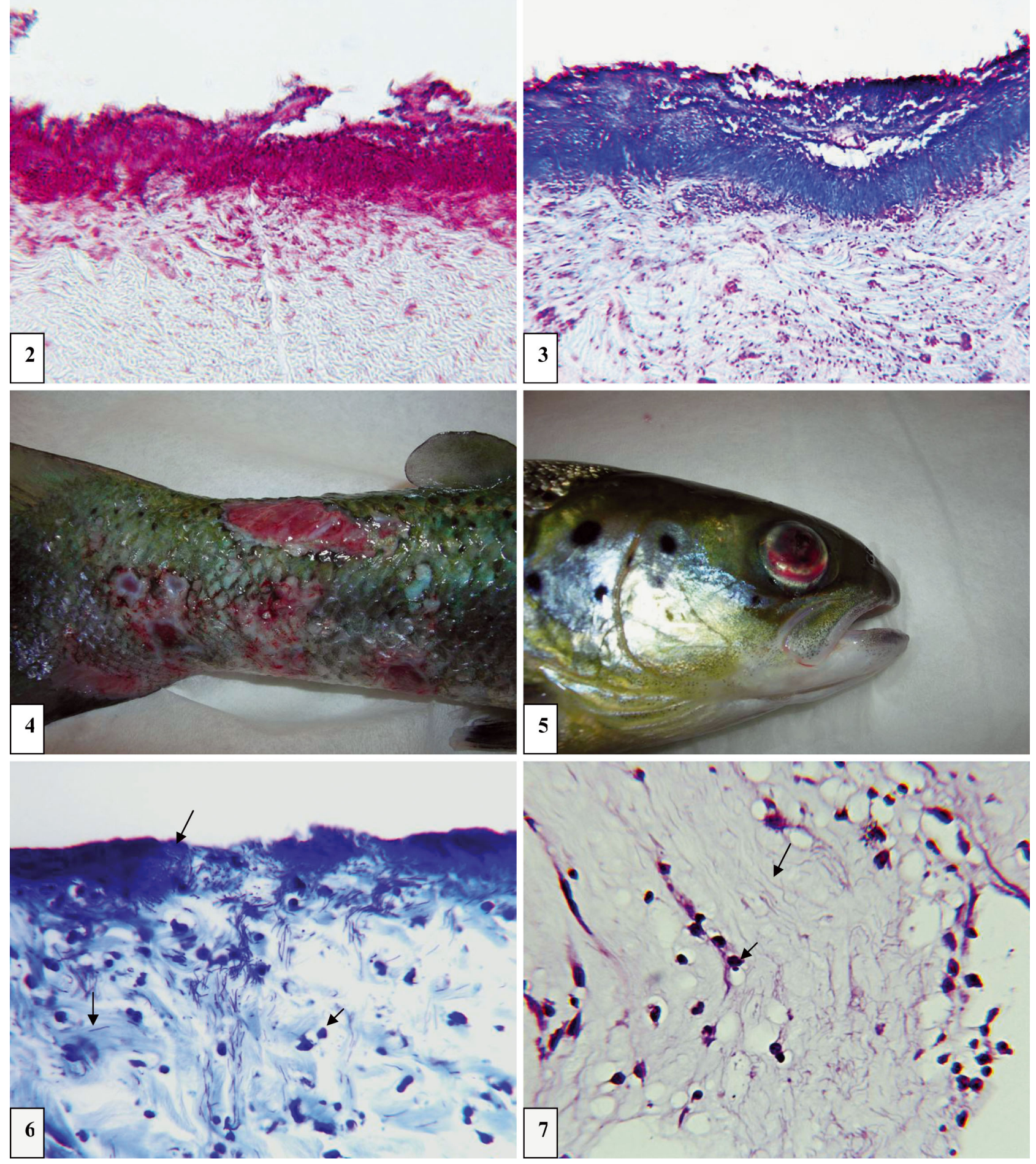

Figs. 2 to 7. Salmo salar. Experimental infection of Atlantic salmon with Tenacibaculum sp. Fig. 2. Skin ulcer showing positive immunostaining with antiserum against the Group 1 bacterium (red colour) from fish simultaneously exposed to Group 1 and Group 2 bacterium by bath challenge for $1 \mathrm{~h}$ following development of Moritella viscosa-induced ulcers (Expt 2$)(\times 400)$. Fig. 3. Same ulcer immunostained with antiserum against $M$. viscosa (red colour) $(\times 400)$. Fig. 4. Skin ulcers in tail root area of fish bathchallenged for $7 \mathrm{~h}$ with the Group 1 bacterium (Expt 3). Fig. 5. Cornea ulcer and haemorrhage in the eye of fish from Expt 3. Fig. 6. Photomicrograph of skin ulcer from fish in Expt 3, showing infection in dermis with long, slender rods (long arrows) and inflammatory cells (short arrow) (May-Grünwald-Gemsa, MGG, ×400). Fig. 7. Photomicrograph of cornea of the eye from fish in Expt 3 infected with long, slender rods (long arrow) and inflammatory cells (short arrow) (H\&E, $\times 400$ ) 
ulcers only, $M$. viscosa-like bacteria were found and, in 2 ulcers, which appeared to be in the reparative stage, no bacteria were detected. By immunohistochemical examination, the long, slender rods stained positively with antisera against the Group 1 bacterium (F95B/98) (Fig. 2), but not with antisera against the Group 2 bacterium (F95C/98). Figs. 2 \& 3 illustrate concurrent infection in an ulcer with $M$. viscosa and the Group 1 bacterium. None of the non-exposed fish in Tank C developed ulcers.

In Expt 3, where fish were exposed to bacterium F95B/98 by bath challenge for $7 \mathrm{~h}$, all 5 deeply scarified fish developed an ulcer in the scarified area. The 3 fish with superficial scarification also developed smaller ulcers in the damaged area. Multiple skin ulcers, especially in the caudal area, developed in 1 deeply and 2 superficially scarified fish (Fig. 4). Few to several small haemorrhagic, slightly protruding skin lesions were identified on the lateral surfaces of all but one fish. All deeply scarred fish also developed eye damage with corneal inflammation with part-perforation, bilaterally in 2 fish and unilaterally in 3 fish (Fig. 5). In the first fish examined, $3 \mathrm{~d}$ post-challenge, inflammation and long, slender rods positively stained by immunohistochemistry against the Group 1 bacterium and negatively stained against the Group 2 bacterium were seen in cornea and eye lumen, skin lesions on the abdomen and tail root and in the ulcer that developed in the scarified area (Figs. 6 \& 7). Severe inflammation, oedema and muscle necrosis were detected in the lesions of all remaining fish, but no bacteria were identified. No fish in the control group or those exposed to $\mathrm{MB}$ developed ulcers or corneal pathology.

\section{DISCUSSION}

The prominent finding of long, slender bacteria in skin lesions from cases of winter ulcers in Atlantic salmon, as seen by histopathology in the present study, has not previously been reported. Studies based on cultivation alone report Moritella viscosa and to some extent Vibrio wodanis, as the most important specific bacteriological results related to this condition (Lunder et al. 1995, Benediktsdóttir et al. 1998, Bruno et al. 1998). In those studies, $M$. viscosa was the dominating finding in 30,40 and $40 \%$ of the outbreaks investigated, respectively. This is in accordance with our findings based on cultivation alone, as $M$. viscosa was the most common bacterium isolated in the present study: it was detected in 42 and $48 \%$ of the lesions during our 2 sampling periods, respectively (data not shown).

The high prevalence of long, slender rods observed by histopathology compared with the low prevalence of such bacteria isolated, especially in the 1996 study, shows that these bacteria, if present, are likely to be highly underdiagnosed when skin lesions in field cases of winter ulcers are examined by cultivation alone, even with the use of MA.

Our inclusion of MA for isolation, in addition to the media used in previous studies (BA and BAS, Lunder et al. 1995 ; TSA with $2 \% \mathrm{NaCl}$, TSA-NaCl with $10 \%$ blood and modified Anacker and Ordal's medium, Bruno et al. 1998; and BAS, Benediktsdóttir et al. 1998), did, to some extent, increase the sensitivity of cultivation as a detection method. During the 20042005 study, we improved our isolation rate utilising firm scraping of sample material from the ulcer surface. There is, however, an obvious need for further improvement of both the growth conditions and the method of sampling from fish tissues.

The 2 strains, representing 2 distinct groups of long, slender rods isolated during our study of outbreaks of winter ulcers are consistent phenotypically and genetically with the Cytophaga-Flavobacterium-Bacterioides group. In common with many species within the Flavobacteriaceae, these bacteria were isolated from an aquatic environment. Both strains are Gram-negative, strictly aerobic, long rods and grow as yellowpigmented colonies on MA. They form threadlike flexible cells and present spherical degenerative inflations and coccoid bodies with age. More specifically, the available phenotypic evidence is supported by the genetic testing and indicates that, although the studied isolates belong to the genus Tenacibaculum (Suzuki et al. 2001), they differ sufficiently from previously described Tenacibaculum spp. (Hansen et al. 1992, Suzuki et al. 2001, Frette et al. 2004, Yoon et al. 2005, Jung et al. 2006, Sheu et al. 2007, Heindl et al. 2008, Piñeiro-Vidal et al. 2008a,b, Wang et al. 2008, Lee et al. 2009) and may constitute 2 new species or subspecies within this genus.

When field ulcers with long, slender rods were tested by immunohistochemistry with antisera raised against Group 1 and Group 2 bacteria, positive staining against the Group 1 bacterium was identified in all samples investigated, whereas positive staining against the Group 2 bacterium was never observed. This indicated that Group 1 isolates may be of importance in the development of winter ulcers whereas Group 2 appear to be of no or minor significance. The lack of Group 2 bacterium could be explained by poor invasive properties. This hypothesis was subsequently confirmed in our challenge experiments. Following challenge with a suspension containing both bacteria, only the Group 1 bacterium was detected in ulcers. Our experiment with the Group 1 bacterium alone also confirmed this bacterium as a causative agent of skin and corneal ulcers. 
The specificity of our polyclonal antiserum may be questioned, and possible cross-reactions with related bacteria must be taken into account, but in the present case the infection was reproduced experimentally and was therefore unlikely to have been affected by the presence of a cross-reacting contaminating bacterium. In addition, no cross-reaction was observed when a panel including different members of the genus Tenacibaculum was tested by slide-agglutination.

Although skin ulcers were produced following the $1 \mathrm{~h}$ bath challenge, they were only observed in the scarified area. Prolonged exposure, i.e. $7 \mathrm{~h}$, to the Group 1 bacterium did, however, result in the development of multiple ulcers and keratitis. A higher dose $\left(4.2 \times 10^{7} \mathrm{CFU} \mathrm{ml}^{-1}\right.$ compared with $\left.1.2 \times 10^{6} \mathrm{CFU} \mathrm{ml}^{-1}\right)$ and/or higher water temperature $\left(12^{\circ} \mathrm{C}\right.$ compared with $9.5^{\circ} \mathrm{C}$ ) could also have contributed to the result, but increased immersion time is in accordance with the recommendation by Avendaño-Herrera et al. (2006) for successful challenge with Tenacibaculum maritimum (increasing from $1-2 \mathrm{~h}$ to $18 \mathrm{~h}$ in their experiments with turbot). It may be speculated that the accumulation of large numbers of bacteria and the subsequent development of a biofilm on the skin surface is necessary before tissue damage and infection can occur (Avendaño-Herrera et al. 2006).

An important finding in the present study was that Moritella viscosa-related skin lesions appear to represent a pre-disposing factor for infection with Group 1 bacterium, as immersion for $1 \mathrm{~h}$ was sufficient to produce relatively heavy infections with this bacterium in such lesions. It was also in this experiment (Expt 2) that the redetection of the Group 1 bacterium with time was most consistent. This could be due to the facilitated access to favourable tissues for infection and proliferation of the Group 1 bacterium, but there is also a possibility of a synergistic relationship between these 2 bacteria, which should be looked into further.

Two findings could indicate a more effective inflammatory antigen-eliminating reaction in the cases when $M$. viscosa was absent. (1) No antigen was redetected after $4 \mathrm{~d}$ in ulcers that were produced by the $1 \mathrm{~h}$ challenge with both Group 1 and Group 2 bacteria (Expt. 1). (2) There was a decrease in bacteria over time in those ulcers produced with the Group 1 bacterium only (Expt. 3). This may also point towards the involvement and importance of exotoxins in the primary development of lesions.

The histopathological finding identified in the present study, in natural as well as experimental cases, resembled those described by Handlinger et al. (1997) in relation to natural infection with Tenacibaculum maritimum, a bacterium which has never been reported in Norway. As for T. maritimum, the long rods in the Norwegian cases may occur as a mat on the eroded surface of the ulcer and appear to have an affinity for collagenous tissue, e.g. dermis and intermuscular connective tissue. Orientation parallel to the collagen bundles is also described for the saddles produced by Flavobacterium columnare (prev. Flexibacter columnaris) (Morrison et al. 1981). In the present study, the affinity for collagen was also seen as infection in the collagenous cornea of the eye.

With regards to possible virulence factors of the Group 1 bacterium, the results so far are limited. Like most bacteria in the Cytophaga-Flavobacterium-Bacteroides complex, they have proteolytic properties, and identification of large numbers of cells in collagenous tissue also indicates collagenophilia. A collagenbinding adhesin was shown to be a virulence factor for some strains of Staphylococcus aureus causing keratitis in de-epithelialized corneas in a rabbit model (Rhem et al. 2000). Whether a similar mechanism is important for the virulence of our bacterium is not known. The observed degeneration and necrosis in white muscle may be related to bacterial toxic components. The histopathological results as described revealed some very interesting features of the bacterium that should be further investigated to elucidate the true nature of the infection.

Although confirmed as primary pathogens, natural infection by Tenacibaculum maritimum and Flavobacterium columnare seems to be seen only after abrasion of the skin surface. It should be noted that Moritella viscosa is also generally absent in early skin lesions with intact epidermis (data not shown) (Salte et al. 1994). Likewise, in our field cases the long, slender rods were only seen in open lesions with lost epidermis and were never detected on or in the epidermis in the periphery of the ulcer.

The exact pathogenic role of our bacterium for the development of winter ulcers has yet to be determined. The bacterium may mainly contribute to the production of ulcers in already mechanically abrated skin, due to handling, etc., or as a secondary infection in e.g. Moritella viscosa-induced skin lesions and thereby contribute to the aggravation of the ulcer development and probably also prevent healing. The Group 1 bacterium should, however, also be taken into account as a primary pathogen under field conditions, as we have shown that the virulence of the bacterium may overwhelm the defence of the host and produce ulcers of skin and eye.

The inclusion of a Group 1-positive skin ulcer from an outbreak in 1988 supports the finding that this bacterium is widely spread geographically within the area investigated over a considerable period of time. That Group 1 bacteria were also found in skin ulcers of cod, halibut and rainbow trout shows that a range of fish species may be affected and that these bacte- 
ria may also be of importance in the development of ulcers in these species. This should be investigated further.

In conclusion, the high prevalence of large numbers of Group 1 bacteria within skin lesions in Atlantic salmon suffering from winter ulcers and the experimental reproduction of infection with this bacterium strongly indicate the importance of this group in the pathogenesis of winter ulcers in Norway. The available data indicate that the 2 groups of bacteria identified in the present study are phenotypically and genetically different and may constitute previously undescribed species or sub-species within the genus Tenacibaculum. The work of precise taxonomic placement of these 2 groups of bacteria is now under way.

Acknowledgements. We thank Local fish health practitioners for collecting samples. We are also most grateful for the technical assistance provided by E. Soltvedt for histopathology and bacteriology, A. Sundstrom and the late I. Hernar for immunohistochemistry, K. Bottolfsen for bacteriology (all from the NVIB) and H. Rudra (Institute of Marine Research) for the transmission experiments. The study was partly funded by the Norwegian Research Council (NFR.1588824).

\section{LITERATURE CITED}

Altschul SF, Gish W, Miller W, Myers EW, Lipman DJ (1990) Basic local alignment search tool. J Mol Biol 215: 403-410

Anacker RL, Ordal EJ (1959) Studies on the myxobacterium Chondrococcus columnaris. J Bacteriol 78:25-32

> Avendaño-Herrera R, Toranzo AE, Magariñ B (2006) A challenge model for Tenacibaculum maritimum infection in turbot, Scophthalmus maximus (L.). J Fish Dis 29: 371-374

> Benediktsdóttir E, Helgason S, Sigurjónsdóttir H (1998) Vibrio spp. isolated from salmonids with shallow skin lesions and reared at low temperature. J Fish Dis 21:19-28

$>$ Bernardet JF (1989) 'Flexibacter columnaris': first description in France and comparison with bacterial strains from other origins. Dis Aquat Org 6:37-44

Bernardet JF, Grimont PAD (1989) Deoxyribonucleic acid relatedness and phenotypic characterization of Flexibacter columnaris sp. nov., nom. rev., Flexibacter psychrophilus sp. nov., nom. rev., and Flexibacter maritimus Wakabayashi, Hikida, and Masumura 1986. Int J Syst Bacteriol 39:346-354

> Bernardet JF, Kerouault B (1989) Phenotypis and genomic studies on 'Cytophaga psychrophila' isolated from diseased rainbow trout (Oncorhynchus mykiss) in France. Appl Environ Microbiol 55:1796-1800

Bernardet JF, Campbell AC, Buswell JA (1990) Flexibacter maritimus is the agent of 'black patch necrosis' in Dover sole in Scotland. Dis Aquat Org 8:233-237

Borg AF (1960) Studies on myxobacteria associated with diseases in salmonid fishes. J Wildl Dis 8:1-85

$>$ Bruno DW, Griffiths J, Petrie J, Hastings TS (1998) Vibrio viscosus in farmed Atlantic salmon Salmo salar in Scotland: field and experimental observations. Dis Aquat Org 34: 161-166
Fautz E, Reichenbach H (1980) A simple test for flexirubintype pigments. FEMS Microbiol Lett 8:87-91

Frette L, Jørgensen NOG, Irming H, Kroer N (2004) Tenacibaculum skagerrakense sp. nov., a marine bacterium isolated from the pelagic zone in Skagerrak, Denmark. Int J Syst Evol Microbiol 54:519-524

$>$ Handlinger J, Soltani M, Percival S (1997) The pathology of Flexibacter maritimus in aquaculture species in Tasmania, Australia. J Fish Dis 20:159-168

Hansen GH, Bergh Ø, Michaelsen J, Knappskog D (1992) Flexibacter ovolyticus sp. nov., a pathogen of eggs and larvae of Atlantic halibut, Hippoglossus hippoglossus L. Int J Syst Bacteriol 42:451-458

Heindl H, Wiese J, Imhoff JF (2008) Tenacibaculum adriaticum sp. nov., from a bryozoan in the Adriatic Sea. Int J Syst Evol Microbiol 58:542-547

Johnson JL, Chilton WS (1966) Galactosamine glycan of Chondrococcus columnaris. Science 152:1247-1248

Jung SY, Oh TK, Yoon JH (2006) Tenacibaculum aestuarii sp. nov., isolated from a tidal flat sediment in Korea. Int J Syst Evol Microbiol 56:1577-1581

Kent ML, Dungan CF, Elston RA, Holt RA (1988) Cytophaga sp. (Cytophagales) infection in seawater pen-reared Atlantic salmon Salmo salar. Dis Aquat Org 4:173-179

$>$ Lee YS, Baik KS, Park SY, Kim EM and others (2009) Tenacibaculum crassostreae sp. nov., isolated from the Pacific oyster, Crassostrea gigas. Int J Syst Evol Microbiol 59:1609-1614

> Løvoll M, Wiik-Nielsen CR, Tunsjø HS, Colquhoun D, Lunder T, Sørum H, Grove S (2009) Atlantic salmon bath challenged with Moritella viscosa-pathogen invasion and host response. Fish Shellfish Immunol 26:877-884

Lunder T, Evensen Ø, Holstad G, Håstein T (1995) 'Winter ulcer' in the Atlantic slamon Salmo salar. Pathological and bacteriological investigations and transmission experiments. Dis Aquat Org 23:39-49

- Morrison C, Cornick J, Shum G, Zwicker B (1981) Microbiology and histopathology of 'saddleback' disease of underyearling Atlantic salmon, Salmo salar L. J Fish Dis 4: $243-258$

- Piñeiro-Vidal M, Riaza A, Santos Y (2008a) Tenacibaculum discolor sp. nov. and Tenacibaculum gallaicum sp. nov., isolated from sole (Solea senegalensis) and turbot (Psetta maxima) culture systems. Int J Syst Evol Microbiol 58: $21-25$

Piñeiro-Vidal M, Carballas CG, Gómez-Barreiro O, Riaza A, Santos Y (2008b) Tenacibaculum soleae sp. nov., isolated from diseased sole (Solea senegalensis Kaup). Int J Syst Evol Microbiol 58:881-885

- Rhem MN, Lech EM, Patti JM, McDevitt D, Höök M, Jones DB, Wilhelmus KR (2000) The collagen-binding adhesin is a virulence factor in Staphylococcus aureus keratitis. Infect Immun 68:3776-3779

> Salte R, Rørvik KA, Reed E, Norberg K (1994) Winter ulcers of the skin in Atlantic salmon, Salmo salar L.: pathogenesis and possible aetiology. J Fish Dis 17:661-665

> Sheu SY, Lin KY, Chou JH, Chang PS, Arun AB, Young CC, Chen WM (2007) Tenacibaculum litopenaei sp. nov., isolated from a shrimp mariculture pond. Int J Syst Evol Microbiol 57:1148-1153

> Sørensen UB, Larsen JL (1986) Serotyping of Vibrio anguillarum. Appl Environ Microbiol 51:593-597

> Suzuki M, Nakagawa Y, Harayama S, Yamamoto S (2001) Phylogenetic analysis and taxonomic study of marine Cytophaga-like bacteria: proposal for Tenacibaculum gen. nov. with Tenacibaculum maritimum comb. nov. and Tenacibaculum ovolyticum comb. nov., and description of 
Tenacibaculum mesophilum sp. nov. and Tenacibaculum amylolyticum sp. nov. Int J Syst Evol Microbiol 51: 1639-1652

Swofford DL (2000) PAUP*: phylogenetic analysis using parsimony ( ${ }^{*}$ and other methods). Sinauer Associates, Sunderland, MA

Thompson JD, Gibson TJ, Plewniak F, Jeanmougin F, Higgins DJ (1997) The Clustal X windows interface: flexible strategies for multiple sequence alignment aided by quality analysis tools. Nucleic Acids Res 25:4876-4882

> Wakabayashi H, Hikida M, Masumura K (1986) Flexibacter maritimus sp. nov., a pathogen of marine fishes. Int J Syst Bacteriol 36:396-398

Editorial responsibility: David Bruno,

Aberdeen, UK
Wakabayashi H, Huh GJ, Kimura N (1989) Flavobacterium branchiophila sp. nov., a causative agent of bacterial gill disease of freshwater fishes. Int J Syst Bacteriol 39:213-216

Wang JT, Chou YJ, Chou JH, Chen CA, Chen WM (2008) Tenacibaculum aiptasiae sp. nov., isolated from a sea anemone Aiptasia pulchella. Int J Syst Evol Microbiol 58: 761-766

Weisburg WG, Barns SM, Pelletier DA, Lane DJ (1991) 16S ribosomal DNA amplification for phylogenetic study. J Bacteriol 173:697-703

Yoon JH, Kang SJ, Oh TK (2005) Tenacibaculum lutimaris sp. nov., isolated from a tidal flat in the Yellow Sea, Korea. Int J Syst Evol Microbiol 55:793-798

Submitted: May 21, 2010; Accepted: December 14, 2010 Proofs received from author(s): April 15, 2011 